\title{
Functional diversity of bacterial genes associated with aromatic hydrocarbon degradation in anthropogenic dark earth of Amazonia
}

\author{
Mariana Gomes Germano(1), Fabiana de Souza Cannavan(2), Lucas William Mendes(2), Amanda Barbosa Lima(2), \\ Wenceslau Geraldes Teixeira ${ }^{(3)}$, Vivian Helena Pellizari ${ }^{(4)}$ and Siu Mui Tsai( ${ }^{(2)}$ \\ (1)Embrapa Soja, Rodovia Carlos João Strass, Distrito de Warta, Caixa Postal 231, CEP 86001-970 Londrina, PR, Brazil. \\ E-mail: mgermano@cnpso.embrapa.br (2)Universidade de São Paulo (USP), Centro de Energia Nuclear na Agricultura, Laboratório de \\ Biologia Molecular e Celular, Avenida Centenário, № 303, CEP 13400-970 Piracicaba, SP, Brazil. E-mail: cannavan@cena.usp.br, \\ Iwmendes@cena.usp.br, ablima@cena.usp.br, tsai@cena.usp.br (3)Embrapa Solos, Rua Jardim Botânico, no 1.024, Jardim Botânico \\ CEP 22460-000, Rio de Janeiro, RJ, Brazil. E-mail: wenceslau@cnps.embrapa.br (4)USP, Instituto Oceanográfico, Laboratório de Ecologia de \\ Microrganismos, Praça do Oceanográfico, no 191, Cidade Universitária, CEP 05508-900 São Paulo, SP, Brazil. E-mail: vivianp@usp.br
}

Abstract - The objective of this work was to evaluate the catabolic gene diversity for the bacterial degradation of aromatic hydrocarbons in anthropogenic dark earth of Amazonia (ADE) and their biochar (BC). Functional diversity analyses in ADE soils can provide information on how adaptive microorganisms may influence the fertility of soils and what is their involvement in biogeochemical cycles. For this, clone libraries containing the gene encoding for the alpha subunit of aromatic ring-hydroxylating dioxygenases ( $\alpha$-ARHD bacterial gene) were constructed, totaling 800 clones. These libraries were prepared from samples of an ADE soil under two different land uses, located at the Caldeirão Experimental Station - secondary forest (SF) and agriculture (AG) -, and the biochar (SF_BC and AG_BC, respectively). Heterogeneity estimates indicated greater diversity in BC libraries; and Venn diagrams showed more unique operational protein clusters (OPC) in the SF_BC library than the ADE soil, which indicates that specific metabolic processes may occur in biochar. Phylogenetic analysis showed unidentified dioxygenases in ADE soils. Libraries containing functional gene encoding for the alpha subunit of the aromatic ring-hydroxylating dioxygenases (ARHD) gene from biochar show higher diversity indices than those of ADE under secondary forest and agriculture.

Index terms: catabolic genes, genetic diversity, land use systems, microbial ecology, tropical soils.

\section{Diversidade funcional de genes bacterianos associados à degradação de hidrocarbonetos aromáticos em solos de terra preta de índio}

\begin{abstract}
Resumo - O objetivo deste trabalho foi avaliar a diversidade de genes catabólicos quanto à degradação bacteriana de hidrocarbonetos aromáticos, em solos de terra preta de índio (TPI) e seu "biochar" (BC). Análises da diversidade funcional em solos TPI podem fornecer dados sobre como os microrganismos adaptativos podem influenciar a fertilidade dos solos e qual é sua participação nos ciclos biogeoquímicos. Para isso, foram construídas bibliotecas que continham o gene que codifica a subunidade alfa de dioxigenases aromáticas ( $\alpha$-ARHD gene bacteriano), no total de 800 clones. Estas bibliotecas foram preparadas a partir de amostras de um solo TPI localizado na Estação Experimental do Caldeirão, sob dois diferentes usos da terra - floresta secundária (SF) e agricultura (AG) - e de "biochar" (SF_BC e AG_BC, respectivamente). Os estimadores de heterogeneidade apresentaram maior diversidade nas bibliotecas BC, e o diagrama de Venn mostrou mais famílias proteicas operacionais (OPC) únicas na biblioteca SF_BC do que o solo TPI, o que indica que processos metabólicos específicos podem ocorrer no "biochar". A análise filogenética mostrou dioxigenases ainda não identificadas em solos de TPI. Bibliotecas para o gene funcional da subunidade alfa de dioxigenases aromáticas (ARHD) obtidas do "biochar", mostraram maiores índices de diversidade do que as da TPI sob floresta secundária ou agricultura.
\end{abstract}

Termos para indexação: genes catabólicos, diversidade genética, sistemas de uso da terra, ecologia microbiana, solos tropicais.

\section{Introduction}

The Anthrosols associated with pre-Colombian settlements in the Amazonian region are examples of how anthropogenic activities can promote the metabolic diversity of microbial populations in soil. Unlike most tropical soils, Anthrosols contain large pools of stable soil organic matter and are highly fertile. These soils, also known as the anthropogenic dark earth of Amazonia (ADE) or "terra preta de índio",

Pesq. agropec. bras., Brasília, v.47, n.5, p.654-664, maio 2012 
exhibit approximately three times more organic matter, nitrogen and phosphorus, along with the presence of potsherds.

Content of charred biomass of unknown organic origin or pyrogenic black carbon, referred in the present study as biochar (BC), is 70 times higher in $\mathrm{ADE}$, in comparison to their adjacent infertile soils (ADJ) without a past history of anthropogenic activities (Glaser, 2007). Biochar is the major structural distinction between the "terra preta de índio" and the adjacent soils and also constitutes an important fraction of many soils worldwide, playing an important role in global carbon biogeochemistry (Liang et al., 2010). Because of its highly aromatic structure, biochar is chemically and biologically stable and remains in the environment for thousands of years.

In ADE soils, the organic matter consists of approximately 35\% pyrogenic black carbon along the anthropogenic A horizon, whereas in the adjacent Oxisols to ADE soils, the biochar occurs only in the first centimeters of the soil profile, constituting about $14 \%$ of soil organic matter (SOM). The biochar stocks within $1 \mathrm{~m}$ soil depth in the ADE soils was estimated by Glaser et al. (2001) as being 4 to 11 times higher than in the ADJ soils without an anthropogenic profile, along with an increase in clay content.

Many studies have tried to verify whether the fertility of ADE soils is caused only by its mineralogical characteristics or also by the presence of high amounts of organic carbon (Grossman et al., 2010). The Anthrosols along with their biochar have distinct microbial communities that are responsible for unique processes, such as high-labile $\mathrm{C}$ retention, which have been observed in these soils (O'Neill et al., 2009). However, functional microbial communities in these soils, related with important carbon and nitrogen biogeochemical cycles, have yet to be described.

Biodegradation due to bacterial activity is one of the most important processes occurring in soils, regarding organic matter recycling, and involves genes which may develop a key role in carbon cycle for the turnover of more recalcitrant organic carbon (Iwai et al., 2010). These processes, along with biosynthesis, largely govern the carbon cycle, which is dependent on microbial enzymes which use organic compounds as a carbon and energy source (Wackett, 2004).

The role of enzymatic catalysis in global biogeochemical cycles has been increasingly recognized with the Bacteria domain as a major contributor in carbon turnover due to competition for resources in soil. Accordingly, multicomponent enzymes catalyze the insertion of molecular oxygen into benzene rings, a common first step in the bacterial degradation of aromatic compounds. Rieske non-heme iron aromatic ring-hydroxylating dioxygenases (ARHD) comprise a reductase which obtains electrons from $\mathrm{NAD}(\mathrm{P}) \mathrm{H}$, often a ferredoxin which shuttles the electrons and a catalytic oxygenase component. The oxygenase frequently incorporates both atoms of oxygen into the substrate and can have either a homo- $(\alpha n)$ or a hetero-oligomeric $(\alpha n \beta n)$ structure (Kweon et al., 2008). The alpha subunit contains the catalytic domain, and genes encoding for this subunit are often used as markers to study the biodegradation of aromatic compounds in the environment (Gibson \& Parales, 2000). Due to sequence conservation, the alpha subunit has been used as a target for detection of bacterial functional diversity in contaminated and pristine environments.

The diversity of catabolic genes for aromatic hydrocarbon degradation in anthropogenic soils and their biochar were evaluated in order to determine the role of black carbon in microbial diversity and, consequently, on soil resilience. Using a primer set designed with basis on conserved regions of the dioxygenase alpha subunit from previously described biodegradation pathways (Bellicanta, 2004), specific clusters of dioxygenase gene fragments were identified in biochar from SF and AG libraries, most of them distantly related to previously described sequences.

The objective of this work was to evaluate catabolic gene diversity for the bacterial degradation of aromatic hydrocarbons in anthropogenic dark earth of Amazonia (ADE) and their biochar (BC).

\section{Materials and Methods}

Four strains, namely Pseudomonas putida (DSM 291), P. fluorescens (DSM 6506), P. putida F1 (DSM 6899) and P. fluorescens (DSM 8369) were purchased from DSMZ (Leibniz-Institut DSMZ - German Collection of Microorganisms and Cell Cultures, Braunschweig, Germany). These strains were used as reference strains for PCR-amplification of the ARHD dioxygenase genes by specific primers. 
The work was undertaken in central Amazônia (Amazon basin), near Manaus. The Caldeirão Experimental Station is located at Embrapa Amazônia Ocidental, in the Iranduba region, and includes two distinct ADE sites, one of which has been used for agricultural practices for over 30 years (AG site), while the other site has been under a tropical secondary forest for at least 20 years (SF site). The territory is an experimental station, where surveys are conducted with grains, vegetables, manioc and fish farming, among other research. Soil samples were collected from two ADE sites: SF (at 01³0'26.4"S, 6005'34"W), and AG (at $01^{\circ} 30^{\prime} 26.4^{\prime \prime S}$ and $60^{\circ} 05^{\prime} 34^{\prime \prime} \mathrm{W}$, under a semi-permanent manioc culture). At both sites, the biochar content, the dark color and the presence of ceramic fragments in the anthrosols were the soil characteristics which were consistently different from sites of adjacent and anthropic soils; therefore, the influence of biochar (BC) on the soil bacterial community was also investigated.

Soil samples were taken with a sterilized plastic tube of $5 \mathrm{~cm}$ in diameter and $10 \mathrm{~cm}$ length at $0-10 \mathrm{~cm}$ depth, discarding the overlaying litter. At each site, one georeferenced point was selected (central), four different points (1.50 $\mathrm{m}$ apart) were sampled, and three subsamples were collected summing up to 15 samples per site. Each sample contained around $300 \mathrm{~g}$ of wet soil. Samples were immediately frozen and kept at $-20^{\circ} \mathrm{C}$ until their use. Out of the total soil samples collected at each site, five ones were considered for genomic DNA extractions of the ADE soil. In addition, the BC collection was carefully performed under sterile conditions at $4{ }^{\circ} \mathrm{C}$, using a magnifier to facilitate the screening of biochar from the soil. Community DNA, for both soil and biochar samples, was extracted using the Power Soil DNA Isolation Kit (MOBIO Laboratories, Carlsbad, CA, USA), according to the manufacturer's instructions.

Total DNA extracted from ADE soils and BC samples was amplified by polymerase chain reaction (PCR) using the primers for the $\alpha$-ARHD gene region ARHD-2F (5'-TTYRYITGYAIITAYCAYGGITGGG-3') and ARHD-2R (5'-AAITKYTCIGCIGSIRMYTTCCA-3') (Bellicanta, 2004). Triplicate PCR products for soil sample were analyzed by gel electrophoresis and purified using the Qiagen PCR purification kit (Qiagen, Valencia, CA, USA). Each $25 \mu \mathrm{L}$ reaction mixture contained approximately $40 \mathrm{ng}$ of template DNA, 1X PCR buffer
(Invitrogen, Carlsbad, CA, USA), $1.5 \mathrm{mmol} \mathrm{L}^{-1} \mathrm{MgCl}_{2}$, $0.2 \mathrm{mmol} \mathrm{L}^{-1}$ of each deoxynucleoside triphosphate, $1.2 \mu \mathrm{mol} \mathrm{L}^{-1}$ of each forward (F) and reverse (R) primer, and 1.0 U of Platinum Taq DNA polymerase(Invitrogen). PCR mixtures were incubated in a GeneAmp PCR System 9700 thermal cycler (Applied Biosystems, Foster City, CA, USA) for the following amplification cycling: $97^{\circ} \mathrm{C}$ for $3 \mathrm{~min}$; 30 cycles consisting of $94^{\circ} \mathrm{C}$ for $1 \mathrm{~min}$, $55^{\circ} \mathrm{C}$ for $1 \mathrm{~min}$, and $72^{\circ} \mathrm{C}$ for $1 \mathrm{~min}$; and $72^{\circ} \mathrm{C}$ for $5 \mathrm{~min}$. PCR products were ligated into the pGEM-T easy vector (Promega, Madison, WI, USA) and transformed into competent $E$. coli $\mathrm{DH} 5 \alpha$ cells to construct $\mathrm{ADE}$ and $\mathrm{BC}$ libraries. Two hundred clones of each ADE soil were randomly selected and sequenced, as well as the same amount of BC clones for each "terra preta de índio" site, in a total of 800 clones. Sequencing was performed with SP6 (5'-ATTTAGGTGACACTATAGAA-3') and T7 (5'-TAATACGACTCACTATAGGG-3') promoter primers, the DYEnamic ET Terminator Cycle Sequencing Kit (GE Healthcare, São Paulo, SP) and an ABI PRISM 3100 Genetic Analyzer capillary sequencer (Applied Biosystems, Foster City, CA, USA).

The obtained sequences were compared to the GenBank database (National Center for Biotechnology Information, 2012), using the basic local alignment search tool TBlastX (McGinnis \& Madden, 2004). Clones showing no matches with dioxygenases were removed for further analyses, as these fragments were assumed to be produced as the result of mispriming events. Sequences with low quality according to phredPhrap assembling were also removed. A phylogenetic tree, using the deduced amino acid sequences from representative clones of each library, was constructed using the neighbor-joining algorithm in the molecular evolutionary genetics analysis software Mega 4 (Tamura et al., 2007). To test the inferred phylogeny, a bootstrap test with 1,000 replications was used.

The Mothur software (Schloss et al., 2009) was used to group sequences based on distance at the amino acid level (0.05 cut-off). The Shannon's diversity and Simpson's dominance indices were also computed, and the Chao-Jaccard abundance-based similarity index was calculated as well. Library coverage indices were calculated as described by Good (1953). Venn diagrams were developed based on the $\alpha$-ARHD gene libraries, which were separated in bins based on similarity using Mothur to highlight the amount of OPC shared between 
both ADE libraries (SF and AG) and BC libraries (SF_ BC and AG_BC).

The nucleotide sequences, described in this study, have been submitted to the National Center for Biological Information (NCBI) under the accession numbers HQ722216 to HQ722633.

\section{Results and Discussion}

Regarding soil chemical characterization, high values were noted for P, cation exchange capacity (CEC) and soil organic matter (Table 1 ). The high-CEC values were mainly due to organic matter content whose property of organic carbon is specific to soils with a high content of biochar, such as ADE soils. Agricultural management can affect soil properties, including the organic matter chemistry and microbial community structure, but the relationship between these two parameters has not yet been well described (Bünemann et al., 2008). The origin and mineralization processes of soil organic $\mathrm{P}$ are less understood; however, differences in the microbial community composition may also influence

Table 1. Chemical attributes of anthropogenic dark earth of Amazonia soil samples from two different land use systems ${ }^{(1)}$.

\begin{tabular}{|c|c|c|}
\hline Chemical atribute $^{(2)}$ & Secondary forest & Agricultural (manioc culture) \\
\hline $\mathrm{pH}$ in $\mathrm{H}_{2} \mathrm{O}$ & $5.14 \pm 0.45$ & $5.43 \pm 0.19$ \\
\hline $\mathrm{C}\left(\mathrm{g} \mathrm{kg}^{-1}\right)$ & $34.18 \pm 5.52$ & $28.21 \pm 3.64$ \\
\hline $\mathrm{P}\left(\mathrm{mg} \mathrm{dm} \mathrm{d}^{-3}\right)$ & $159 \pm 66.91$ & $339 \pm 248.76$ \\
\hline $\mathrm{K}\left(\mathrm{mg} \mathrm{dm} \mathrm{dm}^{-3}\right)$ & $62 \pm 21.10$ & $42 \pm 20.82$ \\
\hline $\mathrm{Ca}\left(\mathrm{cmol}_{\mathrm{c}} \mathrm{dm}^{-3}\right)$ & $9.22 \pm 2.02$ & $8.28 \pm 1.01$ \\
\hline $\operatorname{Mg}\left(\mathrm{cmol}_{\mathrm{c}} \mathrm{dm}^{-3}\right)$ & $1.34 \pm 0.21$ & $1.50 \pm 0.32$ \\
\hline $\mathrm{Al}\left(\mathrm{cmol}_{\mathrm{c}} \mathrm{dm}^{-3}\right)$ & $0.26 \pm 0.52$ & $0.03 \pm 0.02$ \\
\hline $\mathrm{H}+\mathrm{Al}\left(\mathrm{cmol}_{\mathrm{c}} \mathrm{dm}^{-3}\right)$ & $8.25 \pm 1.90$ & $7.85 \pm 0.90$ \\
\hline $\mathrm{BS}\left(\mathrm{cmol}_{\mathrm{c}} \mathrm{dm}^{-3}\right)$ & $10.74 \pm 2.12$ & $9.91 \pm 1.12$ \\
\hline $\mathrm{t}\left(\mathrm{cmol}_{\mathrm{c}} \mathrm{dm}^{-3}\right)$ & $11.00 \pm 2.35$ & $9.93 \pm 1.12$ \\
\hline $\operatorname{CEC~}\left(\mathrm{cmol}_{\mathrm{c}} \mathrm{dm}^{-3}\right)$ & $19.00 \pm 3.53$ & $17.75 \pm 0.65$ \\
\hline V (\%) & $56.56 \pm 4.57$ & $55.75 \pm 5.30$ \\
\hline
\end{tabular}

${ }^{(1)}$ Means $(\mathrm{n}=5)$ from each sampling point, in each land use system. ${ }^{(2)} \mathrm{BS}$, sum of the bases $(\mathrm{Ca}+\mathrm{Mg}+\mathrm{K})$; $\mathrm{CEC}$, cation exchange capacity $(\mathrm{H}+\mathrm{Al})+\mathrm{Ca}+\mathrm{Mg}+\mathrm{K}) ; \mathrm{t}$, effective $\mathrm{CEC}(\mathrm{Al}+\mathrm{Ca}+\mathrm{Mg}+\mathrm{K}) ; \mathrm{V}$, base saturation $[(\mathrm{Ca}+\mathrm{Mg}+\mathrm{K} / \mathrm{CEC}) \times 100]$. the chemical composition of organic $\mathrm{P}$ in the soil, according to Makarov et al. (2005). Altogether, with favorable $\mathrm{pH}$ values, these chemical properties are responsible for the quality and fertility of ADE soils (Lehmann et al., 2003).

According to Lauber et al. (2009), the soil pH is often the best predictor of bacterial community composition and diversity, compared to the other soil and site characteristics which can be measured. ADE soils commonly show higher $\mathrm{pH}$ values related to original adjacent soils (Glaser, 2007). Bioavailable $\mathrm{Al}$ is highly correlated with soil $\mathrm{pH}$ and bacterial diversity. Lower exchangeable $\mathrm{Al}$ contents in $\mathrm{AG}$ site were observed, which can be directly related with observed $\mathrm{pH}$ variation. Higher-P contents can also be noted in AG site, once P solubility tends to increase in soils with low acidity. These features, together with other soil characteristics (as nutrient availability, organic C contents, plant cover) may largely drive changes in diversity and functionality of soil microbial communities.

All ADE samples produced amplified PCR products of the expected size (approximately $300 \mathrm{bp}$ ), which were used to generate libraries for SF, AG, SF_BC and AG_BC. Two hundred clones from each library (SF, SF_ BC, AG and AG_BC) were sequenced and compared to data from the GenBank database (National Center for Biotechnology Information, 2012). One hundred and sixteen clones from the SF library and 102 clones from the SF_BC library, along with 135 clones from the AG and 65 from the AG_BC libraries, produced significant alignments with dioxygenase sequences deposited in the GenBank database (National Center for Biotechnology Information (Table 2). Most of these matches were associated with aromatic hydrocarbon degradation genes from Bacteria of the genera Pseudomonas, Rhodococcus, Mycobacterium, Bordetella and Bacillus, and many other matches were related to uncultured bacterium clones. This primer set was recently used to amplify ARHD

Table 2. Diversity analysis of anthropogenic dark earth of Amazonia soils and biochar libraries.

\begin{tabular}{lllcccccc}
\hline Land use & \multicolumn{1}{c}{ Library } & $\mathrm{N}$ & OPC & Chao1 & H' & L & Sn & C (\%) \\
\hline \multirow{2}{*}{ Secondary forest } & SF & 116 & 20 & 59.00 & $1.85 \pm 0.35$ & $0.25 \pm 0.08$ & 13 & 90 \\
& SF_BC & 102 & 29 & 56.20 & $2.66 \pm 0.34$ & $0.11 \pm 0.05$ & 17 & 85 \\
\hline \multirow{2}{*}{ Agriculture (manioc culture) } & AG & 135 & 17 & 35.33 & $1.62 \pm 0.30$ & $0.29 \pm 0.07$ & 11 & 93 \\
& AG_BC & 65 & 18 & 40.50 & $2.34 \pm 0.36$ & $0.13 \pm 0.06$ & 10 & 88 \\
\hline
\end{tabular}

SF, secondary forest; AG, agriculture; BC, biochar; N, number of valid sequences; OPC, number of dioxygenase groups; Chao1, richness estimate; H', Shannon's diversity index; L, Simpson's dominance index; Sn, singletons (number of species with only one clone); C (\%), library coverage (Good, 1953). 
genes from a total community DNA, ${ }^{13} \mathrm{C}$-DNA and background-control DNA, from the root zone of an Austrian pine (Pinus nigra L.) growing naturally in a polychlorinated-biphenyl (PCB)-contaminated soil, using a stable isotope probing (SIP) in a functional approach (Leigh et al., 2007).

There were greater differences in diversity between $\mathrm{ADE}$ and BC libraries, where the latter showed a wide variety of bacterial genus for both land uses when compared to ADE (Figure 1). This showed that bacterial communities are heterogeneous and capable of responding distinctly to environmental characteristics and habitats such as biochar, which may support the surveillance of particular and unique microbes. Considering identities at $\geq 95 \%$ ( 0.05 cut-off $)$ protein level among members of the same group, the software Mothur identified 20 distinct groups in the SF library against 29 in the SF_BC library. For the AG libraries, 17 groups for AG and 18 groups for AG_BC were identified. All the analyzed sequences matched translated proteins described as dioxygenases or putative dioxygenases, with E-values from $<10^{-21}$ to $10^{-70}$.

These results suggest that the groups of sequences, identified in the present study, encode the alpha subunit of dioxygenases present in anthropic ADE soils and their biochar fragments. The four libraries were widely diverse, and low-dominance values (L) were presented
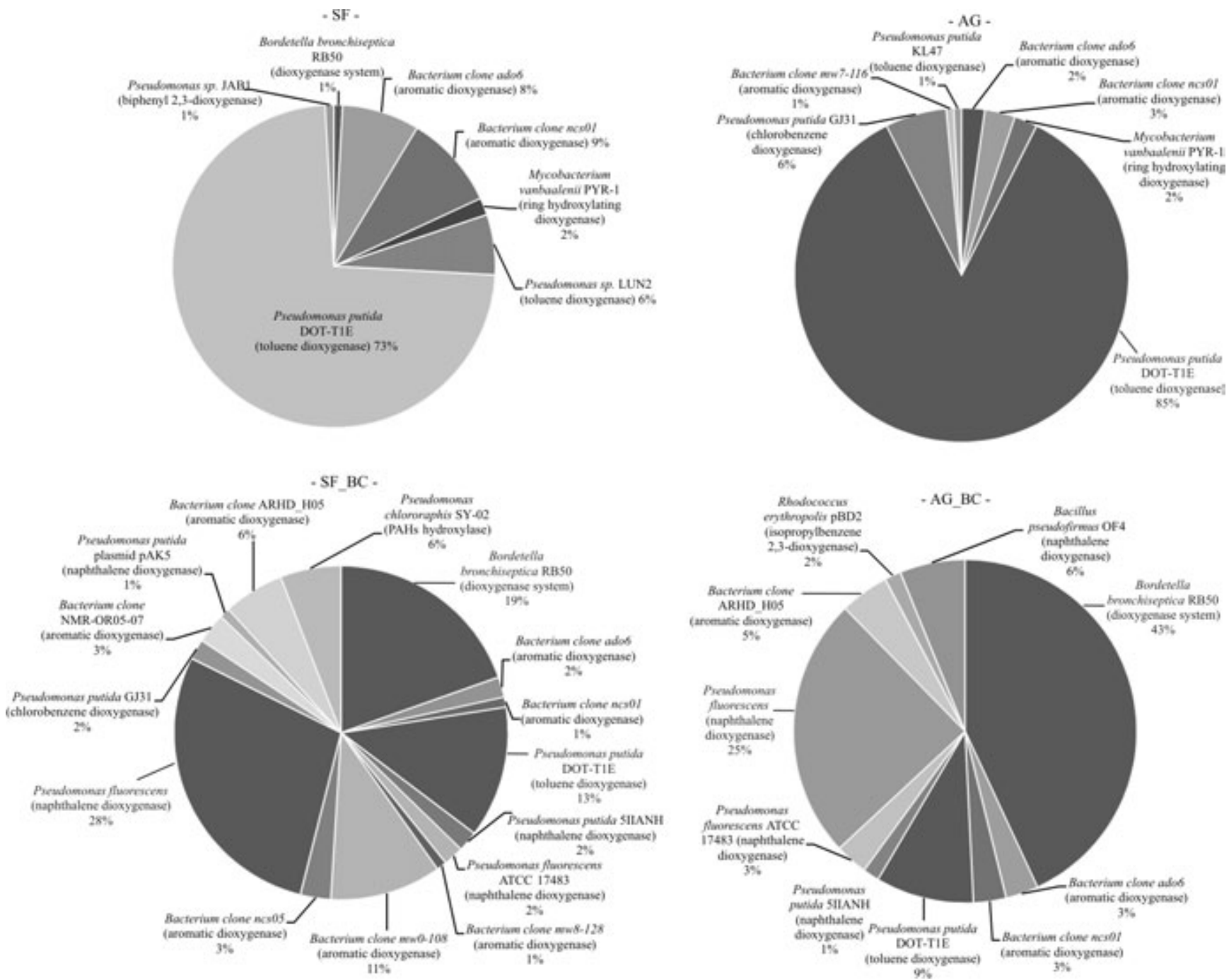

Figure 1. Classification charts of aromatic ring-hydroxylating dioxygenase (ARHD) gene libraries. Classification was performed using the TBlastX tool in the GenBank database (National Center for Biotechnology Information, 2012). SF, secondary forest site; AG, agricultural site; BC, biochar. 
in both BC libraries (Table 2). The diversity estimates indicated that the SF_BC and AG_BC libraries $\left(\mathrm{H}^{\prime}=2.66\right.$ and 2.34 , respectively) were more diverse than the ADE libraries ( $\mathrm{H}^{\prime}=1.85$ for SF and 1.62 for AG). In addition, according to the richness estimate (Chao1), the number of operational protein clusters (OPC), present in the SF_BC library, was significantly higher in comparison to the SF library, whereas, for the AG_BC library, the value was quite a bit higher than for the AG library. In addition, the number of singletons (number of species with only one clone) showed 17 clones for SF_BC against only 13 for the SF library. Otherwise, for both the AG and AG_BC libraries, the number of singletons was almost equal (11 and 10, respectively). The rarefaction curve (Figure 2 $\mathrm{A}$ and $\mathrm{C}$ ) supports the above mentioned results. In both land uses, the curves representing ADE libraries indicated that these samples required a smaller amount of sequences to achieve a comprehensive sampling effort when compared to the BC libraries.
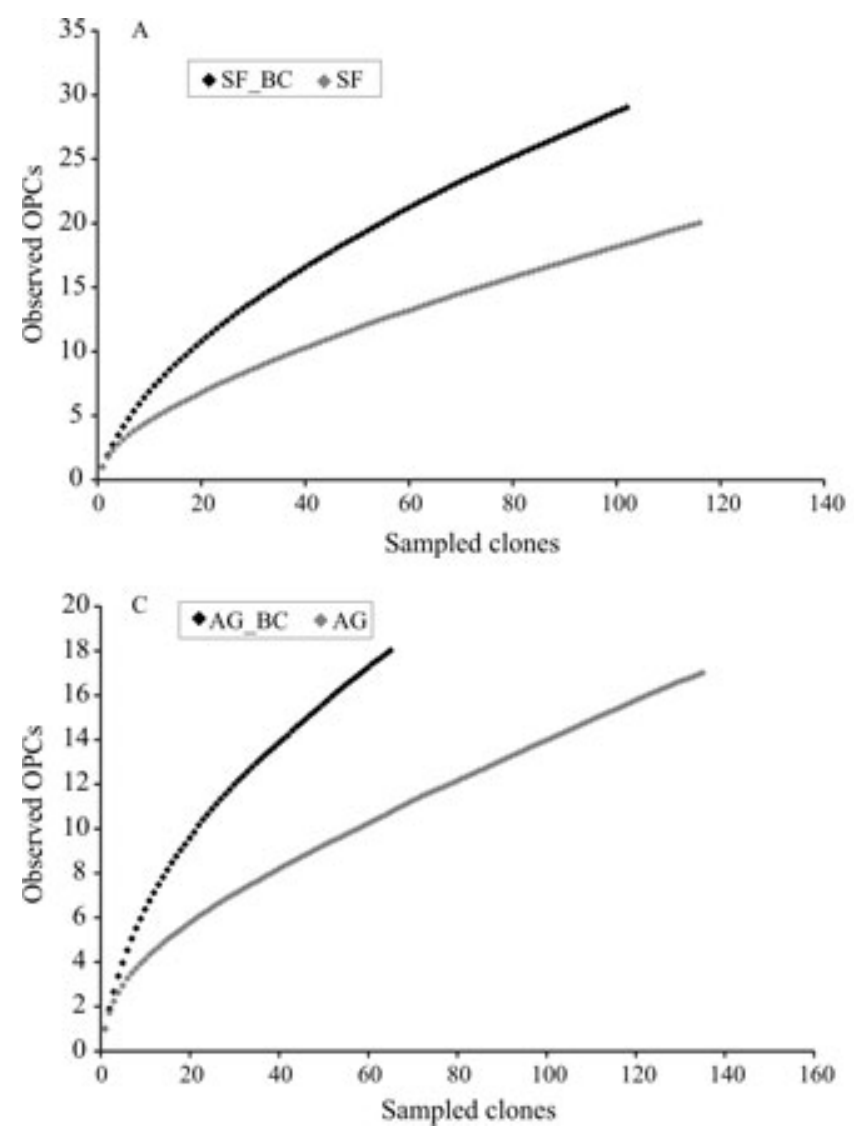

The rarefaction trends are indicative that $\mathrm{BC}$ diversity was greater than in ADE. This also shows that the sampling effort of both libraries was, however, not sufficient to represent the sample of origin. One feature to be noted by the ranking abundance curve, which explains the smaller diversity observed in the ADE libraries for both land uses (SF and AG), is the greater dominance of the most abundant OPC in comparison with the BC libraries (Figure $2 \mathrm{~B}$ and D).

Using a 0.05-evolutionary distance, the number of OPC found in common in the ADE libraries was roughly one third (Figure $3 \mathrm{~A}$ ), and for biochar libraries, the value was almost one quarter of the total OPC (Figure $3 \mathrm{~B}$ ). In both cases, the number of OPC was higher in the SF libraries, suggesting a significant influence of land use on microbial functional diversity. According to Jesus et al. (2009), when studying land conversion from tropical forest to agricultural use, several alterations may occur in the size, activity and composition of the microbial communities,
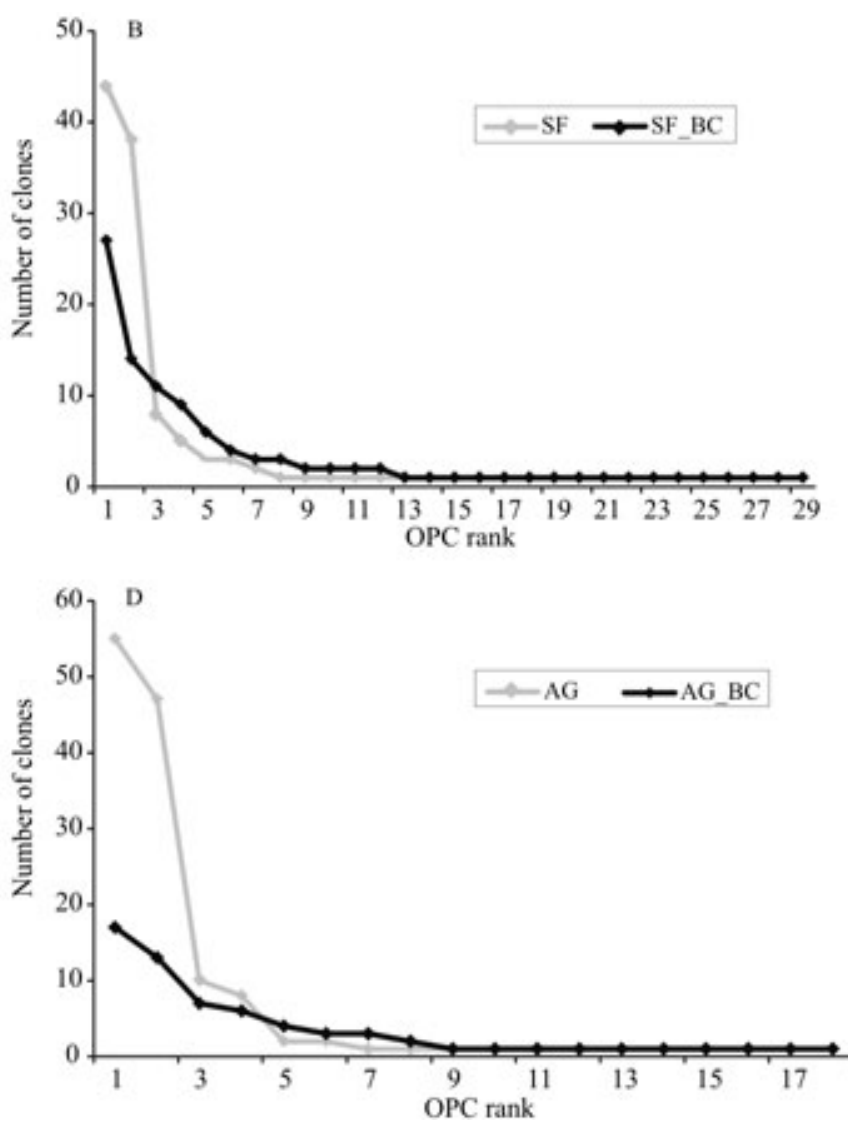

Figure 2. Rarefaction curve analysis of bacterial aromatic ring-hydroxylating dioxygenase (ARHD) gene libraries (A and C), and operational protein clusters (OPC) rank curves from bacterial ARHD gene libraries (B and D). SF, secondary forest site; AG, agricultural site; BC, biochar. 
and unusual microbial communities, like specific functional bacterial groups, may prevail during shifts associated with deforestation (Borneman \& Triplett, 1997; Navarrete et al., 2010). These findings stimulated studies on ADE at high concentrations of $\mathrm{BC}$, as these particles are the oldest form of carbon in the soil (Pessenda et al., 2001), and were found to host a large number of microbes (Grossman et al., 2010). In addition, when the distance cut-off was used to compare ADE soils and their biochar, the amount of unique OPC (Figure $3 \mathrm{C}$ ) in the SF libraries was 33\% higher in biochar, in comparison with ADE. Only four OPC were shared by both, whereas for the AG libraries, the number of OPC for both ADE and biochar was similar, but only two were shared between the libraries (Figure $3 \mathrm{D}$ ). It is considered that high levels of carbon enhance soil fertility, by retaining nutrients and water, and increase the $\mathrm{pH}$ (Glaser, 2007). Additionally, the surface charge properties of biochar are thought to increase the cation exchange capacity, thereby reducing nutrient leaching. However, little is known about the contribution of biochar as a habitat or as a platform for nutrient exchange for microorganisms. While biochar has been appreciated for its chemical adsorption properties, Pietikainen et al. (2000) reported that biochar can support an habitat for microbes. Furthermore, based on the chemical composition and physical structures which are prevalent in biochar particles, Thies \& Rillig (2008) have suggested that biochar has biological properties which are favorable to microbial communities, since residual hydrocarbons and materials adhering to the particle surface may directly support microbes. The idea that Anthrosols may have distinct microbial populations is not new, but recently several facts have indicated the role of biochar on the physical, chemical and biological processes in Anthrosols (Grossman et al., 2010). In the present work, the bacterial functional diversity of biochar was higher than in the anthropogenic dark earth of Amazonia for both land uses. In the comparisons between two ADE libraries and between biochar samples from the SF and AG sites, the number of unique OPC was much higher in the secondary forest site, as showed by the Venn diagram (Figure 3). This result suggests the effect of vegetation and land use on the bacterial catabolic diversity in tropical soils with anthropogenic influence, and the important role of biochar as a niche for bacterial survival and maintenance with a direct role in the biogeochemical $\mathrm{C}$ cycle.
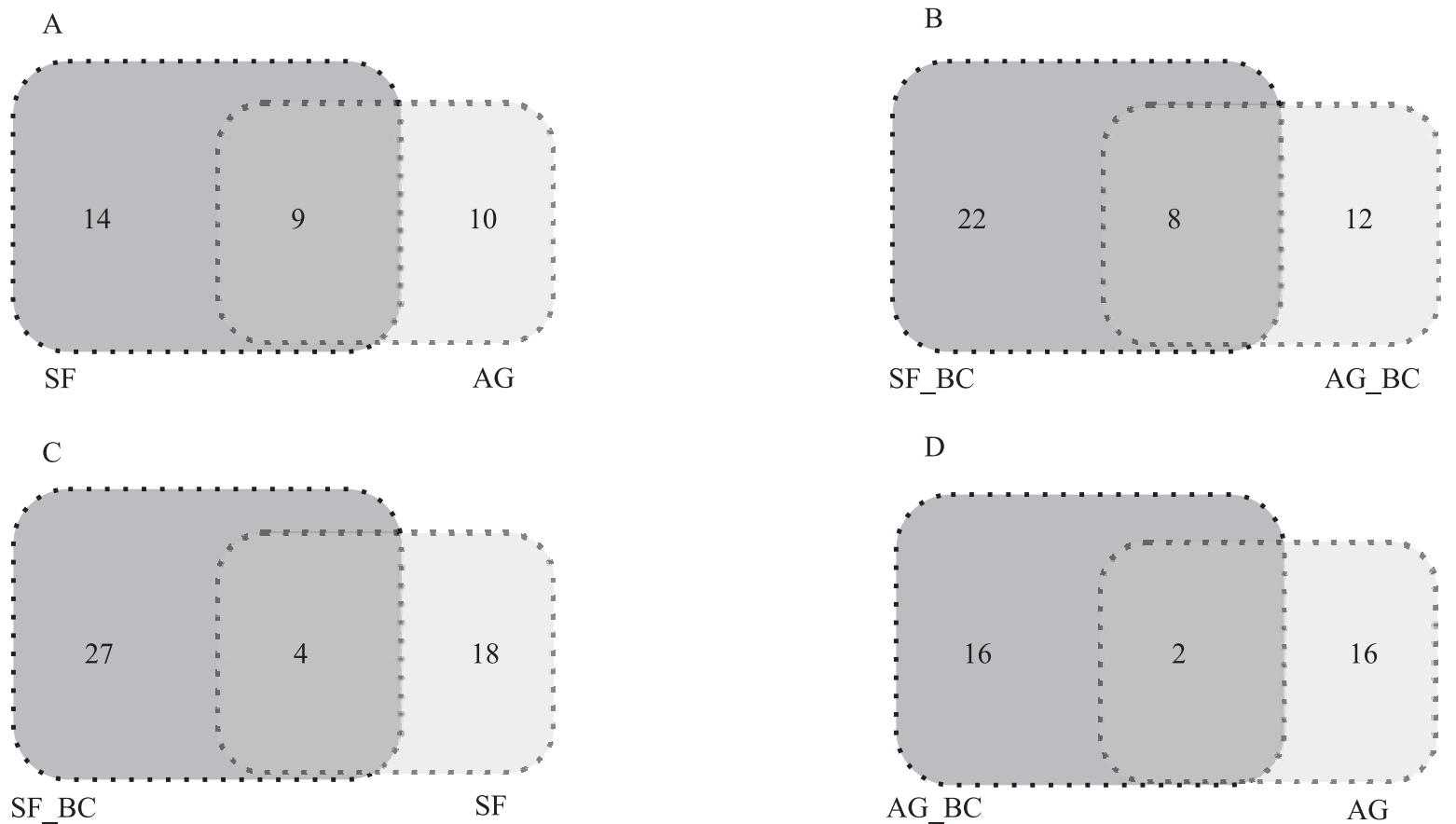

Figure 3. Venn diagram of clones belonging to operational protein clusters (OPC), separated by Mothur software, found in the following site libraries: (A) anthropogenic dark earth of Amazonia (ADE); (B) biochar (BC); (C) secondary forest (SF); and (D) agricultural (manioc culture) (AG). 
Regarding the phylogenetic relationships among dioxygenase sequences, most sequences formed deeply rootedbranches with previously described dioxygenases
(Figure 4). In an effort to classify these highly divergent sequences, it was used a new classification system, recently proposed by Kweon et al. (2008).

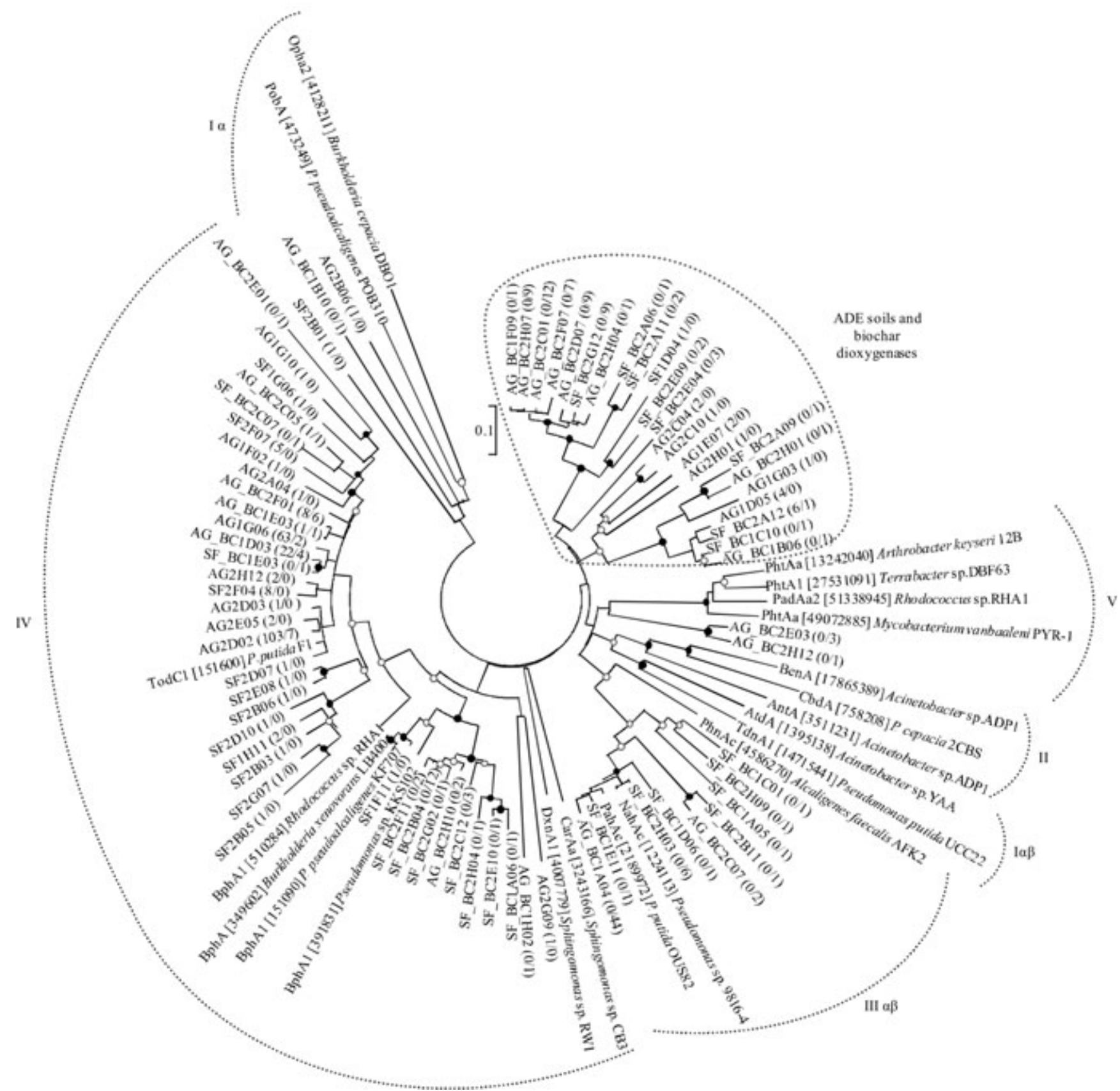

Figure 4. Phylogenetic relationships among aromatic ring-hydroxylating dioxygenase (ARHD) gene clone sequences and selected dioxygenases from the GenBank database. I $\alpha$, IV, III $\alpha \beta$, I $\alpha \beta$, II, V, Kweon dioxygenase group (Kweon et al., 2008). Bootstrap percentages higher than 50\% are shown in the nodes (51-75\%, white circles; $76-100 \%$, black circles). Scale bar: substitutions per amino acid position. Oxygenase types I-V are shown in the tree. Identical sequences at amino acid levels equal to or higher than $95 \%$ were grouped; the number of clones represented by these sequences is shown in parenthesis (ADE/ $\mathrm{BC}$ ). Enzyme names, strains and accession numbers are indicated in the tree. ADE, anthropogenic dark earth of Amazonia; SF, secondary forest site; AG, agricultural site; BC, biochar. 
This classification recognizes five distinct ARHD types, taking into consideration not only the sequence information, but also the interactions between the enzyme components. This is relevant because ARHDs are multicomponent enzymes, as both the oxygenase and the electron transport chain components need to be considered in a functional approach. Moreover, these authors have shown that distance analysis of protein sequences of the oxygenase component can be used for this classification, even when information on the electron transport chain components is not available.

The phylogenetic analyses showed that most of the found protein clusters were heterogeneous and distributed across all the five Kweon's dioxygenase groups (Figure 4). The neighbor-joining tree indicated the formation of seven major groups, each composed of a representative OPC from the four evaluated libraries in this work, including both ADE sites and their biochar. One group (IV) included the majority of amino acid sequences obtained in this work, gathering most of the dominant OPC in all samples. This enzyme type includes mainly biphenyl and polychlorinated biphenyl dioxygenases from diverse genera, it is characterized by the presence of [2Fe-2S]-type ferredoxins in the electron transport chain (Kweon et al., 2008), and is related to the toluene/biphenyl dioxygenase gene, represented by Pseudomonas, Burkholderia, Rhodococcus and Sphingomonas reference sequences. Another major group held a higher number of OPC clustering with the PAH (polycyclic aromatic hydrocarbon) dioxygenase gene (III $\alpha \beta$ ) represented by bacterial naphthalene/phenanthrene degraders. Two representative OPC, including only BC sequences, formed one cluster related to less common dioxygenases (group V). The type $\mathrm{V}$ enzymes are very diverse in terms of substrate, and are characterized by the presence of [3Fe-4S]-type ferredoxins. This type includes enzymes typically found in Gram-positive microorganisms (mostly Actinobacteria): phenanthrene /naphthalene/anthracene dioxygenase from the marine bacterium Nocardioides sp. KP7, phenanthrene and pyrene dioxygenases from Mycobacterium, as well as phthalate dioxygenases from Rhodococcus, Mycobacterium, Terrabacter and Arthrobacter (Kweon et al., 2008).

When analyzing amino acid sequence alignments, it was detected the presence of indels which were shared by the above-mentioned groups, supporting a common origin. Those conserved insertions and deletions (i.e. indels) are signature sequences located at the same position in homologous sequences and flanked by conserved sequence blocks. Despite their rare occurrence because of independent mutational events, they have been used to infer evolutionary relationships among genes (Gupta, 1998). However, the most noticeable group was the one which exclusively held the ADE and biochar sequences, which showed distance values too high to allow of their inclusion in any enzyme type. Moreover, the level of relatedness with previously described sequences was rather low.

There are important knowledge gaps on the structure and diversity of ARHD enzymes, making it difficult to classify them (Marcos et al., 2009). In addition, many reports regarding dioxygenase diversity are related to chronically polluted environments, which is not the case of ADE soils in general. Perhaps because of these facts, this group of dioxygenase previously described in the present study could not be reliably assigned to enzyme types described by Kweon et al. (2008). Taketani \& Tsai (2010) reported a previous study with archaeal communities of the amoA gene in four different ADE sites in Amazônia and their adjacent soils. This functional gene was also involved in major biogeochemical cycles, and the analysis indicated a high similarity between amoA sequences from ADE and adjacent soils (within each site). According to these authors, the factors affecting the structure of amoA communities are ammonium levels, vegetation cover and organic matter, besides the effects of land uses and anthropic activities. However, the way by which these factors could influence the structure of a given community remains unclear. These data suggest that ADE soil microbial populations are very diverse and adapted to the unique biochemical features and ecology of Anthrosols.

\section{Conclusions}

1. Libraries containing functional gene encoding for the alpha subunit of aromatic ring-hydroxylating dioxygenases (ARHD gene) from biochar show higher-diversity indices than the anthropogenic dark earth of Amazonia (ADE) soils under both land uses.

2. The secondary forest site libraries show more unique operational protein clusters (OPC) than the agricultural site, suggesting that soil bacterial diversity 
is strongly influenced by historical Anthrosols management.

3. The recalcitrant biochar in Anthrosols shows unique microbial communities.

\section{Acknowledgements}

To Conselho Nacional de Desenvolvimento Científico e Tecnológico, and to Fundação de Amparo à Pesquisa do Estado de São Paulo, for financial support and fellowships; to Embrapa Amazônia Ocidental, for technical support; to José Elias Gomes and Fábio Duarte, for assistance in the molecular analysis; to Julio Franchini, for helping in discussion.

\section{References}

BELLICANTA, G.S. Diversidade de genes catabólicos em amostras de sedimento do sistema estuarino de Santos e São Vicente, SP. 2004. 112p. Tese (Doutorado) - Universidade de São Paulo, São Paulo.

BORNEMAN, J.; TRIPLETT, E.W. Molecular microbial diversity in soils from Eastern Amazonia: evidence for unusual microorganisms and microbial population shifts associated with deforestation. Applied and Environmental Microbiology, v.63, p.2647-2653, 1997.

BÜNEMANN, E.K.; MARSCHNER, P.; SMERNIK, R.J.; CONYERS, M.; MCNEILL, A.M. Soil organic phosphorus and microbial community composition as affected by 26 years of different management strategies. Biology and Fertility of Soils, v.44, p.717-726, 2008.

GIBSON, D.T.; PARALES, R.E. Aromatic hydrocarbon dioxygenases in environmental biotechnology. Current Opinion in Biotechnology, v.11, p.236-243, 2000.

GLASER, B. Prehistorically modified soils of central Amazonia: a model for sustainable agriculture in the twenty-first century. Philosophical Transactions of the Royal Society B: Biological Sciences, v.362, p.187-196, 2007.

GLASER, B.; HAUMAIER, L.; GUGGENBERGER, G.; ZECH, W. The 'Terra Preta' phenomenon: a model for sustainable agriculture in the humid tropics. Naturwissenschaften, v.88, p.37-41, 2001.

GOOD, I.J. The population frequencies of species and the estimation of population parameters. Biometrika, v.40, p.237-264, 1953.

GROSSMAN, J.M.; O’NEILL, B.E.; TSAI, S.M.; LIANG, B.; NEVES, E.; LEHMANN, J.; THIES, J.E. Amazonian anthrosols support similar microbial communities that differ distinctly from those extant in adjacent, unmodified soils of the same mineralogy. Microbial Ecology, v.60, p.192-205, 2010.

GUPTA, R.S. Protein phylogenies and signature sequences: a reappraisal of evolutionary relationships among Archaebacteria, Eubacteria, and Eukaryotes. Microbiology and Molecular Biology Reviews, v.62, p.1435-1491, 1998.
IWAI, S.; CHAI, B.; SUL, W. J.; COLE, J. R.; HASHSHAM, S. A.; TIEDJE, J. M. Gene-targeted-metagenomics reveals extensive diversity of aromatic dioxygenase genes in the environment. ISME Journal, v.4, p.279-285, 2010.

JESUS, E. da C.; MARSH, T.L.; TIEDJE, J.M.; MOREIRA, F.M.S. Changes in land use alter the structure of bacterial communities in Western Amazon soils. ISME Journal, v.3, p.1004-1011, 2009.

KWEON, O.; KIM, S.-J.; BAEK, S.; CHAE, J.-C.; ADJEI, M.D.; BAEK, D.-H.; KIM, Y.-C.; CERNIGLIA, C.E. A new classification system for bacterial Rieske non-heme iron aromatic ring-hydroxylating oxygenases. BMC Biochemistry, v.9, 2008. Doi:10.1186/1471-2091-9-11.

LAUBER, C.L.; HAMADY, M.; KNIGHT, R.; FIERER, N. Pyrosequencing-based assessment of soil $\mathrm{pH}$ as a predictor of soil bacterial community structure at the continental scale. Applied and Environmental Microbiology, v.75, p.5111-5120, 2009.

LEHMANN, J.; KERN, D.C.; GERMAN, L.; MCCANN, J.; MARTINS, G.C.; MOREIRA, A. Soil fertility and production potential. In: LEHMANN, J.; KERN, D.C.; GLASER, B.; WOODS, W. (Ed.). Amazonian dark earths: origin, properties, management. Dordrecht: Kluwer Academic, 2003. p.105-124.

LEIGH, M.B.; PELLIZARI, V.H.; UHLÍK, O.; SUTKA, R.; RODRIGUES, J.; OSTROM, N.E.; ZHOU, J.; TIEDJE, J.M. Biphenyl-utilizing bacteria and their functional genes in a pine root zone contaminated with polychlorinated biphenyls (PCBs). ISME Journal, v.1, p.134-148, 2007.

LIANG, B.; LEHMANN, J.; SOHI, S.P.; THIES, J.E.; O’NEILL, B.; TRUJILLO, L.; GAUNT, J.; SOLOMON, D.; GROSSMAN, J.; NEVES, E.G.; LUIZAO, F.J. Black carbon affects the cycling of non-black carbon in soil. Organic Geochemistry, v.41, p.206-213, 2010.

MAKAROV, M.I.; HAUMAIER, L.; ZECH, W.; MARFENINA, O.E.; LYSAK, L.V. Can ${ }^{31} \mathrm{P}$ NMR spectroscopy be used to indicate the origins of soil organic phosphates? Soil Biology and Biochemistry, v.37, p.15-25, 2005.

MARCOS, M.S.; LOZADA, M.; DIONISI, H.M. Aromatic hydrocarbon degradation genes from chronically polluted Subantarctic marine sediments. Letters in Applied Microbiology, v.49, p.602-608, 2009.

MCGINNIS, S.; MADDEN, T.L. BLAST: at the core of a powerful and diverse set of sequence analysis tools. Nucleic Acids Research, v.32, p.20-25, 2004.

NATIONALCENTERFORBIOTECHNOLOGYINFORMATION. GenBank. Available at: <http://www.ncbi.nlm.nih.gov/genbank/>. Accessed on: 28 May 2012.

NAVARRETE, A.A.; CANNAVAN, F.S.; TAKETANI, R.G.; TSAI, S.M. A molecular survey of the diversity of microbial communities in different Amazonian agricultural model systems. Diversity, v.2, p.787-809, 2010.

O’NEILL, B.; GROSSMAN, J.; TSAI, S.M.; GOMES, J.E.; LEHMANN, J.; PETERSON, J.; NEVES, E.; THIES, J.E. Bacterial community composition in Brazilian anthrosols and adjacent soils characterized using culturing and molecular identification. Microbial Ecology, v.58, p.23-35, 2009. 
PESSENDA, L.C.R.; GOUVEIA, S.E.M.; ARAVENA, R. Radiocarbon dating of total soil organic matter and humin fraction and its comparison with C-14 ages of fossil charcoal. Radiocarbon, v.43, p.595-601, 2001.

PIETIKAINEN, J.; KIIKKILA, O.; FRITZE, H. Charcoal as a habitat for microbes and its effect on the microbial community of the underlying humus. Oikos, v.89, p.231-242, 2000.

SCHLOSS, P.D.; WESTCOTT, S.L.; RYABIN, T.; HALL, J.R.; HARTMANN, M.; HOLLISTER, E.B.; LESNIEWSKI, R.A.; OAKLEY, B.B.; PARKS, D.H.; ROBINSON, C.J.; SAHL, J.W.; STRES, B.; THALLINGER, G.G.; VAN HORN, D.J.; WEBER, C.F. Introducing Mothur: open-source, platform-independent, community supported software for describing and comparing microbial communities. Applied and Environmental Microbiology, v.75, p.7537-7541, 2009.
TAKETANI, R.G.; TSAI, S.M. The influence of different land uses on the structure of archaeal communities in Amazonian anthrosols based on 16S rRNA and amoA genes. Microbial Ecology, v.59, p.734-743, 2010.

TAMURA, K.; DUDLEY, J.; NEI, M.; KUMAR, S. MEGA4: molecular evolutionary genetics analysis (MEGA) software version 4.0. Molecular Biology and Evolution, v.24, p.1596-1599, 2007.

THIES, J.E.; RILLIG, M.C. Characteristics of biochar: biological properties. In: LEHMANN, J.; JOSEPH, S. (Ed.). Biochar for environmental management: science and technology. London: Dunstan House, 2008. p.85-106.

WACKETT, L.P. Evolution of enzymes for the metabolism of new chemical inputs into the environment. Journal of Biological Chemistry, v.279, p.41259-41262, 2004.

$\overline{\text { Received on January 30, } 2011 \text { and accepted on April 18, } 2012}$ 